\title{
Zeolites of the clinoptilolite-heulandite type in sediments of south-east England
}

\author{
G. BROWN, J. A. CATT, AND A. H. WEIR \\ Pedology Department, Rothamsted Experimental Station, Harpenden, Herts.
}

\begin{abstract}
s U M M AR Y. Clinoptilolite-heulandite is reported from Jurassic, Cretaceous, and Palaeocene sediments in south-east England. It occurs mainly in $\mathrm{I}-20 \mu \mathrm{m}$ size fractions, and is associated with abundant montmorillonite and often also with glauconite and amorphous silica or low-temperature disordered cristobalite-tridymite. Its mode of occurrence and the associated minerals suggest an authigenic origin, but there is no evidence that the source material was volcanic.
\end{abstract}

ZeOLITES of the clinoptilolite-heulandite type occur in many sedimentary rocks, particularly those containing volcanic materials (Hay, 1966), but they have not been reported from English deposits. During routine X-ray examination of soil clays from many parts of England and Wales a weak reflection at $d 9.0 \AA$ was noted in several specimens from Buckinghamshire and Berkshire. Subsequent examination of various. size fractions from soil of the Harwell series (derived from the malmstone facies of the Upper Greensand) showed that the mineral giving the $9 \cdot 0 \AA$ reflection was a major constituent of the coarse clay $(0 \cdot 2-2 \mu \mathrm{m})$ and silt $(2-50 \mu \mathrm{m})$. Powder patterns of the enriched fractions gave further reflections, which corresponded with heulandite or clinoptilolite (table I). We have searched for this mineral in many Mesozoic and Cenozoic sediments throughout southern England, and can now report its stratigraphic and geographic distribution in detail. It is most abundant in the malmstone and the basal Thanet Beds.

Clinoptilolite and heulandite are closely related, and the distinction between them is not completely clear. Hey and Bannister (1934) defined clinoptilolite as a silica-rich member of the heulandite structural group, and Mumpton (1960) suggested that the molecular silica/alumina ratio of clinoptilolite is 8.5-10.0 whereas that of heulandite is 5.5-6.5. However, Mason and Sand (1960) suggested that the difference depends on the amounts of lime and alkalis, $\mathrm{Ca}$ predominating in heulandite and $\mathrm{Na}+\mathrm{K}$ in clinoptilolite. X-ray powder diffraction patterns of the two minerals are very similar, but Mason and Sand stated that $\beta$ is $<1.485$ for clinoptilolite and $>1.488$ for heulandite. Since 1960 the name clinoptilolite has been widely used for zeolites with a diffraction pattern similar to heulandite, but with $\beta<\mathrm{I} \cdot 485$, molecular silica/ alumina ratio $>8.0$ and $\mathrm{Na} ; \mathrm{K}>\mathrm{Ca}$. These have been reported mainly from sediments containing pyroclastic material, though Hay (I966) listed a few occurrences of zeolites of this type in marine sediments not containing appreciable amounts of volcanic detritus. In the text we use 'clinoptilolite' for members of this group, although many properties of the zeolites we have examined are intermediate between those: given for heulandite and clinoptilolite. 


\section{Mineralogy}

$X$-ray powder examination. Table I gives X-ray powder data for zeolite concentrates from a Harwell series soil at Halton, Buckinghamshire (SP 867I I2), and from basal Thanet Beds at Upnor, Kent (TQ 753700). The purified zeolite was obtained in different ways from these two source materials, because their mineralogy differed. Separation of the $<2.3$ S.G. fraction of the silt from the Halton soil gave a mixture of zeolite and silica; some of the silica was amorphous and some low-temperature disordered cristobalite-tridymite. ${ }^{1}$ However, zeolite was also obtained from the sand fractions $(>50 \mu \mathrm{m})$ of the soil, which contain many sub-spherical, micro-crystalline aggregates ranging from 70 to $300 \mu \mathrm{m}$ in diameter. X-ray powder patterns were obtained from individual aggregates; the patterns were not good, because the specimens were too small, but they sufficed to show that four main types of aggregate occur. These contain respectively zeolite, zeolite plus cristobalite-tridymite, cristobalitetridymite plus quartz, and amorphous silica. The optical properties of the aggregates agree with this range of mineralogical composition, as some are isotropic with refractive index near $\mathrm{I} \cdot 45$ whereas others are birefringent in part and have refractive indices near $\mathrm{x} \cdot 47$. We selected enough material of the first type for more detailed examination, and the X-ray powder pattern of this is given in table I, column $\mathrm{I}$. Even this material contained some quartz and probably also a little cristobalitetridymite; the reflections caused by impurities are marked in the table.

The basal Thanet Beds at Upnor, Kent contain neither cristobalite-tridymite nor opaline silica, and consequently yielded an almost pure zeolite sample. The coarse silt $(20-50 \mu \mathrm{m})$ was separated by repeated sedimentation in distilled water containing no deflocculating agents. This fraction was centrifuged in a liquid of S.G. 2.3, and the light separate subdivided into magnetic and non-magnetic fractions. These treatments removed quartz, felspar, mica, glauconite, and other heavy minerals from the coarse silt, and the powder pattern of the non-magnetic fraction (table I, column 2) shows that a small amount of quartz was the only detectable impurity.

The powder patterns of these two zeolites are almost identical; however, the material from the Halton soil gives sharper reflections, and this allows the detection of some reflections that cannot be seen in the pattern of the Thanet Beds material. Comparison with powder patterns of minerals identified as clinoptilolite and heulandite (table I, columns 3-6) shows that our zeolites belong to this group. Mumpton (1960) suggested that clinoptilolite and heulandite can be distinguished by thermal tests, in particular that the powder pattern of clinoptilolite is unaffected by heating to $450^{\circ} \mathrm{C}$ whereas heulandite is rendered amorphous. Heating at $450^{\circ} \mathrm{C}$ for $\mathrm{I} 6$ hours did not destroy the patterns of our zeolites, but decreased their intensity. The patterns persist, although considerably weakened, even after heating at $650^{\circ} \mathrm{C}$ for 16 hours. This suggests either that the zeolite is intermediate between clinoptilolite and heulandite or that it is a mixture of the two.

\footnotetext{
I We use this descriptive term for material characterized by an X-ray powder pattern consisting of reflections with $d$ spacings $4.33 \AA$ (medium), 4.09 (strong), 2.50 (medium). These reflections are those of a one-dimensionally disordered stacking sequence of the silica layers found in cristobalite and tridymite (see Flörke, 1955a, 1955b).
} 
TABLE I. X-ray powder diffraction patterns of zeolite from south-east England compared with those of clinoptilolite and heulandite; spacings in $A$

\begin{tabular}{|c|c|c|c|c|c|c|c|c|c|c|c|}
\hline \multicolumn{2}{|l|}{1} & \multicolumn{2}{|l|}{2} & \multicolumn{2}{|l|}{3} & \multicolumn{2}{|l|}{4} & \multicolumn{2}{|l|}{5} & \multicolumn{2}{|l|}{6} \\
\hline$d$ & $I$ & $d$ & $I$ & $d$ & $I$ & $d$ & $I$ & $d$ & $I$ & $d$ & $I$ \\
\hline $12.0 \AA$ & 2 & - & - & II.9 $\AA$ & 4 & - & - & - 8 & - & - & - \\
\hline $8 \cdot 98$ & 9 & $9.06 \AA$ & 8 & 8.94 & 9 & $8.96 \AA$ & 10 & $9.00 \AA$ & 10 & $8.845 \AA$ & 8 \\
\hline 7.96 & 8 & 7.96 & 7 & 7.92 & 8 & 7.94 & 6 & 7.94 & 4 & $7 \cdot 796$ & 7 \\
\hline 6.84 & 6 & $6 \cdot 82$ & 5 & $6 \cdot 82$ & 7 & $6 \cdot 80$ & 4 & $6 \cdot 77$ & 3 & & - \\
\hline 6.65 & 4 & $6 \cdot 68$ & 4 & - & 一 & - & - & $6 \cdot 64$ & 2 & 6.631 & 6 \\
\hline 5.95 & 4 & 5.97 & 3 & 5.93 & 5 & - & - & $5.9 \mathrm{I}$ & I & 5.945 & I \\
\hline 5.59 & 2 & 5.59 & I & 5.57 & I & - & - & - & - & 一 & - \\
\hline 5.25 & 6 & $5 \cdot 27$ & 6 & $5 \cdot 25$ & 2 & - & - & $5 \cdot 24$ & 3 & 5.277 & 5 \\
\hline 5.12 & 7 & $5 \cdot \mathrm{II}$ & 6 & $5 \cdot 11$ & 7 & $5 \cdot 13$ & 6 & $5 \cdot \mathrm{II}$ & I & 5.096 & 7 \\
\hline $4 \cdot 66$ & 7 & $4 \cdot 67$ & 6 & $4 \cdot 63$ & 6 & $4 \cdot 65$ & 4 & $4 \cdot 69$ & 2 & $4 \cdot 646$ & 6 \\
\hline 4.49 & 2 & - & - & - & - & - & - & $4 \cdot 48$ & 2 & - & - \\
\hline 436 & 6 & $4 \cdot 36$ & 4 & $4 \cdot 34$ & 6 & $4 \cdot 35$ & 4 & $4 \cdot 34$ & 2 & $4 \cdot 364$ & 2 \\
\hline $4 \cdot 26$ & $2^{*}$ & $4 \cdot 25$ & $4^{*}$ & - & - & -- & - & - & $\ldots$ & - & - \\
\hline $4 \cdot 10$ & $4^{\dagger}$ & - & - & $4 \cdot \mathrm{II}$ & 3 & - & 一 & - & - & - & - \\
\hline 3.97 & 10 & 3.97 & 10 & $3 \cdot 96 \mid$ & 10 & 3.97 & 10 & 3.96 & 10 & - & - \\
\hline 3.91 & 5 & 3.92 & 6 & $3.91\}$ & 10 & - & 一 & 3.90 & 8 & 3917 & 10 \\
\hline 3.83 & 2 & - & - & - & - & - & - & $3 \cdot 83$ & I & - & - \\
\hline 3.72 & 5 & $3 \cdot 72$ & 5 & $3 \cdot 71$ & 4 & 3.72 & 4 & 3.73 & I & $3 \cdot 723$ & 2 \\
\hline 3.56 & 6 & $3 \cdot 56$ & 6 & 3.55 & 5 & $3 \cdot 55$ & 4 & 3.55 & 2 & 3.562 & 2 \\
\hline $3 \cdot 43$ & 7 & $3 \cdot 43$ & 7 & 342 & 7 & $3 \cdot 43$ & 6 & $3 \cdot 46$ & 2 & - & - \\
\hline $3 \cdot 4 \mathrm{I}$ & 3 & - & - & - & - & - & - & $3 \cdot 42$ & 6 & 3.420 & 7 \\
\hline 3.33 & $5^{*}$ & $3 \cdot 34$ & $6^{*}$ & $3 \cdot 33$ & 5 & $3 \cdot 33$ & 2 & - & - & $3 \cdot 320$ & I \\
\hline 3.17 & 6 & $3 \cdot 17$ & 7 & $3 \cdot 17$ & 5 & $3 \cdot 18$ & 4 & - & - & $3 \cdot 186$ & 5 \\
\hline $3 \cdot 12$ & 5 & $3 \cdot 12$ & 4 & - & - & - & - & $3 \cdot 12$ & 3 & $3 \cdot 132$ & 4 \\
\hline 3.07 & 5 & 3.07 & 4 & 3.08 & 4 & - & - & $3 \cdot 07$ & 2 & - & - \\
\hline 3.02 & I & - & - & - & - & - & - & 3.04 & 2 & - & - \\
\hline $2 \cdot 97$ & 7 & $2 \cdot 97$ & 7 & 2.96 & 7 & $2 \cdot 98$ & 8 & $2 \cdot 97$ & 5 & 2.959 & 9 \\
\hline 2.89 & I & 2.89 & I & - & 一 & - & - & 2.87 & $I$ & - & - \\
\hline - & - & - & - & - & - & - & - & $2 \cdot 82$ & 3 & - & - \\
\hline $2 \cdot 804$ & 7 & $2 \cdot 805$ & 7 & $2 \cdot 789$ & 6 & $2 \cdot 8 \mathrm{I}$ & 6 & 2.80 & I & $2 \cdot 805$ & 7 \\
\hline $2 \cdot 735$ & 5 & $2 \cdot 743$ & 6 & $2 \cdot 718$ & 4 & $2 \cdot 74$ & 4 & $2 \cdot 73$ & I & $2 \cdot 730$ & 4 \\
\hline- & - & - & - & - & - & - & - & $2 \cdot 72$ & 1 & - & - \\
\hline $2 \cdot 674$ & 4 & $2 \cdot 679$ & 4 & 2.668 & 3 & 2.68 & 2 & $2 \cdot 68$ & I & $2 \cdot 667$ & 1 \\
\hline $2.56 \mathrm{I}$ & 3 & $2 \cdot 557$ & 3 & 2.556 & & 2.54 & 4 & - & - & 2.529 & 2 \\
\hline $2 \cdot 528$ & 3 & $2 \cdot 528$ & 3 & - & 4 & - & - & - & - & - & - \\
\hline $2 \cdot 498$ & $2 \dagger$ & - & - & $2 \cdot 484$ & & - & - & - & - & - & - \\
\hline $2 \cdot 455$ & 2 & $2 \cdot 464$ & $5^{*}$ & - & - & $2 \cdot 44$ & 4 & $2 \cdot 44$ & I & - & - \\
\hline 2.423 & 4 & 2.429 & 5 & 2.427 & 5 & - & - & - & - & $2 \cdot 430$ & 3 \\
\hline $2 \cdot 392$ & I & - & - & - & - & - & - & - & - & - & - \\
\hline $2 \cdot 356$ & 3 & $2 \cdot 35^{8}$ & 3 & $2 \cdot 353$ & 3 & $2 \cdot 36$ & 2 & $2 \cdot 38$ & I & $2 \cdot 350$ & I \\
\hline $2 \cdot 318$ & I & - & - & - & - & - & - & - & - & - & $\ldots$ \\
\hline $2 \cdot 280$ & $3^{*}$ & $2 \cdot 28 I$ & $4^{*}$ & $2 \cdot 27 \mathrm{I}$ & 3 & - & - & $2 \cdot 29$ & I & $2 \cdot 270$ & 1 \\
\hline
\end{tabular}


TABLE I (cont.).

\begin{tabular}{|c|c|c|c|c|c|c|c|c|c|c|c|}
\hline \multicolumn{2}{|l|}{ I } & \multicolumn{2}{|l|}{2} & \multicolumn{2}{|l|}{3} & \multicolumn{2}{|l|}{4} & \multicolumn{2}{|l|}{5} & \multicolumn{2}{|l|}{6} \\
\hline$d$ & $I$ & $d$ & $I$ & $d$ & $I$ & $d$ & $I$ & $d$ & $I$ & $d$ & $I$ \\
\hline $2.245 \AA$ & I & - & - & - & - & - & - & & & - & - \\
\hline $2 \cdot 191$ & 3 & $2 \cdot 189 \AA$ & 2 & - & - & $2 \cdot 19 \AA$ & 2 & & & $2 \cdot 196 \AA$ & I \\
\hline $2 \cdot 125$ & $3 \mathrm{~b}$ & $2 \cdot 127$ & $4^{*}$ & - & - & - & - & & & $2 \cdot 120$ & 2 \\
\hline 2.091 & 4 & 2.090 & 4 & $2.077 \AA$ & 3 & 2.09 & 2 & & & 2.078 & 2 \\
\hline 2.058 & 3 & 2.058 & 2 & - & - & - & -- & & & - & - \\
\hline 2.018 & 4 & 2.020 & 3 & $2 \cdot 016$ & 4 & 2.02 & 4 & & & $2 \cdot 010$ & 2 \\
\hline 1.983 & $2^{*}$ & I.98 I & $2^{*}$ & - & - & - & 一 & & & - & - \\
\hline I.962 & 5 & 1.965 & 4 & I.956 & $4 b$ & I.955 & 4 & & & $1 \cdot 963$ & 3 \\
\hline $\mathbf{I} \cdot 939$ & 3 & $\mathrm{I} \cdot 942$ & 2 & - & - & - & - & & & - & - \\
\hline I·924 & 3 & $1 \cdot 929$ & 2 & - & - & - & 一 & & & - & - \\
\hline I $\cdot 857$ & 2 & $I \cdot 863$ & $2 \mathrm{~b}$ & - & - & - & - & & & $\mathrm{I} \cdot 85^{\circ}$ & I \\
\hline $1 \cdot 822$ & $4^{*}$ & 1.820 & $5^{*}$ & I 825 & I & $1 \cdot 829$ & 2 & & & $\mathrm{I} \cdot 8 \mathrm{I} 4$ & I \\
\hline$I \cdot 768$ & 4 & $1 \cdot 77 \mathrm{I}$ & 4 & $I \cdot 760$ & $4 b$ & I. 776 & 2 & & & $\mathrm{I} \cdot 77^{\circ}$ & 3 \\
\hline$I \cdot 750$ & 3 & $I \cdot 754$ & 3 & - & 一 & - & - & & & - & - \\
\hline $1 \cdot 720$ & 4 & I. 733 & 3 & 一 & - & - & - & & & $I \cdot 720$ & I \\
\hline 1.695 & 5 & $1 \cdot 698$ & 4 & $I \cdot 69 I$ & 3 & $1 \cdot 701$ & 2 & & & I. 698 & 2 \\
\hline I.666 & 3 & $I \cdot 672$ & & - & - & - & - & & & $I \cdot 662$ & I \\
\hline$I \cdot 650$ & 3 & - & $3 b$ & - & - & $I \cdot 664$ & 2 & & & - & 一 \\
\hline I.634 & 4 & $I \cdot 635$ & & - & - & - & - & & & $\mathrm{I} \cdot 639$ & I \\
\hline $1 \cdot 618$ & 4 & I.619 & 3 & 一 & - & - & - & & & - & - \\
\hline I. 594 & 4 & I. 595 & 4 & $1 \cdot 583$ & 3 & I. 597 & 2 & & & $I \cdot 607$ & I \\
\hline $1 \cdot 587$ & I & - & - & - & - & - & - & & & I. 585 & I \\
\hline$I \cdot 564$ & 3 & $I \cdot 565$ & 2 & - & - & - & - & & & $\mathrm{I} \cdot 56 \mathrm{I}$ & I \\
\hline I. 542 & $3^{*}$ & $\mathrm{I} \cdot 544$ & $4^{*}$ & 一 & - & - & - & & & - & - \\
\hline $1 \cdot 521$ & 2 & I. 523 & $3 b$ & - & - & $\mathrm{I} \cdot 523$ & 2 & & & $I \cdot 512$ & I \\
\hline $1.499 !$ & $4 \mathrm{~b}$ & I·499 & $a b$ & $\mathrm{I} \cdot 480$ & $3 b$ & $1 \cdot 488$ & 2 & & & -- & -- \\
\hline I.479 I & & I·479 & 40 & - & - & - & - & & & I 473 & I \\
\hline $1 \cdot 453$ & $4^{*}$ & $1 \cdot 455$ & $3^{*}$ & I'45I & 3 & - & - & & & I·449 & I \\
\hline $1 \cdot 437$ & 4 & I.439 & 3 & I. 432 & 3 & - & - & & & $\mathrm{I} \cdot 43 \mathrm{I}$ & I \\
\hline 1.414 & $4^{*}$ & $1 \cdot 418$ & $4^{*}$ & 1413 & 3 & I.416 & 2 & & & - & - \\
\hline I. 400 & I & - & - & - & - & - & - & & & $\mathrm{I} \cdot 40 \mathrm{I}$ & I \\
\hline $1 \cdot 386$ & I & - & - & - & - & - & - & & & - & - \\
\hline $1 \cdot 372$ & $3^{*}$ & I. 374 & $3^{*}$ & - & - & - & - & & & - & - \\
\hline I $\cdot 356$ & 4 & I.359 & 2 & I.35I & 3 & I $\cdot 350$ & 2 & & & $I \cdot 360$ & $\mathbf{I}$ \\
\hline $1 \cdot 342$ & 3 & I'344 & I & - & - & - & - & & & -- & - \\
\hline
\end{tabular}

1. Zeolite from soil, Halton, Buckinghamshire.

2. Zeolite from basal Thanet Beds, Upnor, Kent.

3. Clinoptilolite from Cañadon Hondo, Patagonia.

4. Clinoptilolite from Cañadon Hondo, Patagonia, data from Mason and Sand (1960).

5. Clinoptilolite from Hector, California: data from Mumpton ( 1960 ).

6. Heulandite from Fiesch, Wallis, Switzerland: data from Merkle and Slaughter (1968).

* Part or all of intensity from quartz impurity.

$\dagger$ Part or all of intensity from disordered cristobalite-tridymite impurity.

b Indicates a broadened reflection. 
We tried to distinguish between these two possibilities by heating a sample of the Thanet Beds zeolite for 10 minutes at each $50^{\circ}$ interval between 250 and $700{ }^{\circ} \mathrm{C}$ and examining changes in its powder pattern with increasing temperature. After each heating the sample was cooled in a desiccator, and the low-angle reflections were examined on a heated stage at approximately $\mathrm{I} 50^{\circ} \mathrm{C}$ and at room temperature with a diffractometer. We found no evidence for the heulandite-B modification, which according to Shepard (196I) is characterized by the appearance of a strong reflection

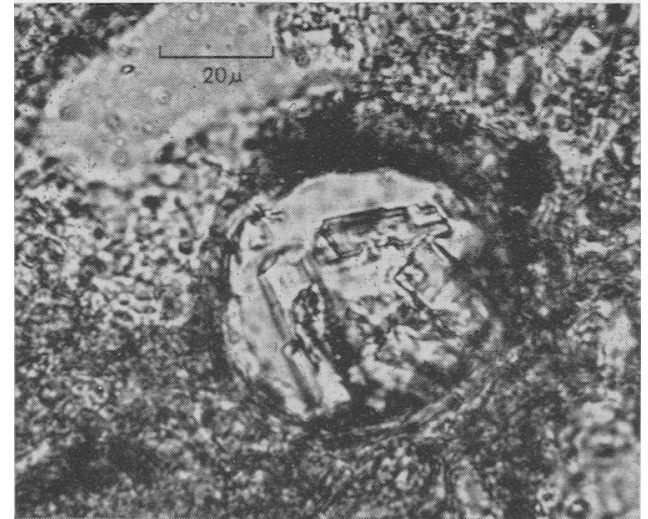

FIG. I. Thin section of malmstone from Shillingford Bridge, Oxfordshire (SU 596920), showing clinoptilolite crystals in a foraminiferal chamber. at $8 \cdot 35 \AA$ replacing the $8 \cdot 96 \AA$ reflection of the unheated material. The only change observed was that the $8 \cdot 96 \AA$ reflection moved to $8 \cdot 86 \AA$ and became more intense when the sample was maintained at $15{ }^{\circ} \mathrm{C}$; on cooling to room temperature the spacing and intensity reverted to that of the unheated material. This reversible change persisted in the sample even after heating to $700^{\circ} \mathrm{C}$, but the intensity of both these reflections was progressively decreased by treatments at increasing temperatures. We cannot decide from these results whether our zeolites are clinoptilolite or heulandite; however, this corresponds with the conclusion of

Shepard and Starkey (1964, 1966) that sedimentary zeolites of this group cannot always be categorized as one or the other.

Crystallography. The crystals of zeolite from crushed samples of malmstone and from soils of the Harwell series are commonly euhedral laths or prisms of orthorhombic aspect; the largest are 50 $\mu \mathrm{m}$ long, IO-20 $\mu \mathrm{m}$ wide and 5-IO $\mu \mathrm{m}$ thick. Many of these occur as aggregates, the individual crystals of which project inwards from a smooth arcuate surface. Thin sections of malmstone from Shillingford Bridge, Oxfordshire (SU 596920) showed that these aggregates occur inside the carapaces of ostracods and chambers of foraminifera (fig. I). Shapeless aggregates of smaller anhedral crystals occur in other pores and cavities of the rock. A grain measuring $40 \times 10 \times 5 \mu \mathrm{m}$ was picked from the coarse silt fraction of a Harwell series subsoil (25-36 in. depth) at Sparsholt, Berkshire (SU 34I874), and examined optically and by X-ray diffraction. In the microscope it seemed to be a single crystal, but zero, first, and second layer equi-inclination Weissenberg patterns of the grain set to rotate about its long axis ( $7 \cdot 4 \AA$ period) showed that it was composed of many small crystals in near parallel orientation with an angular spread of several degrees. The crystal aggregate could not be precisely set because it was small and composite, but our measurements indicate a pseudo-orthorhombic body-centred monoclinic unit cell with $a 7.4, b$ I $7.9, c$ I $5.8 \AA$ and $\beta 9 \mathrm{I}^{\circ}$. This is equivalent to a $C$-face centred monoclinic cell with $a \mathrm{I} 7 \cdot 6, b \mathrm{I} 7{ }^{\circ} 9$, 
c $7.4 \AA$ and $\beta$ II6. Merkle and Slaughter (1968) reported a similar unit cell with $a \mathrm{17} \cdot 73, b 17.82, c 7.43 \AA$ and $\beta 116^{\circ} 20^{\prime}$ for heulandite from Gibels Bach, Switzerland.

Our diffraction patterns also indicated that the $b$ axis is perpendicular to the largest face of the lath. In terms of the pseudo-orthorhombic cell, the grain that we studied, and probably all similarly shaped crystals from the malmstone and soils derived therefrom, are elongated parallel to $c$ and show strong development of \{0IO\} with weaker $\{\mathrm{IOO}\}$ and $\{0 \mathrm{I}\}$ forms. $\{20 \mathrm{I}\}$ and $\{\overline{2} \mathrm{OI}\}$ are sometimes also present. In the grain studied and in most crystals from the malmstone the optic axial plane is perpendicular to (OIO) and $b=\gamma \cdot \alpha:[00 \mathrm{r}]$ is very variable, but usually $70-80^{\circ} ; 2 \mathrm{~V}_{\alpha}$ is $30-60^{\circ} ; \alpha \mathrm{I} \cdot 487, \beta \mathrm{I} \cdot 488, \gamma<\mathrm{r} \cdot 490$.

The Thanet Beds zeolite occurs mainly as aggregates of small colourless subhedral or anhedral crystals, but also in single euhedral crystals as large as $25 \mu \mathrm{m}$ across. Both these forms are distributed throughout the lowest 2-3 ft of the Thanet Beds, and also occur in the underlying Bullhead Bed. The euhedral crystals are tabular, and by analogy with the malmstone crystals are flattened parallel to (oro). They are either eight- or six-sided, probably indicating the development of $\{\mathrm{OOI}\},\{2 \mathrm{OI}\}$, and $\{\overline{2} \mathrm{OI}\}$ forms with or without $\{I 00\}$. The mean refractive index ranges from I.488 to I.49I; birefringence is $<0.005$, but is slightly greater at the margins than in central parts of the crystals, suggesting slight changes in composition during or after crystallization.

Chemical analysis was possible only with the Thanet Beds zeolite, because the zeolite in the malmstone and in soils of the Harwell series could not be separated from the associated amorphous silica and low-temperature disordered cristobalite-tridymite. A sub-sample dried at $105{ }^{\circ} \mathrm{C}$ of the light (S.G. $<2 \cdot 3$ ) non-magnetic coarse silt from the basal Thanet Beds at Upnor, Kent (i.e. part of the same silt fraction as that used for X-ray powder examination) gave: $\mathrm{SiO}_{2} 64 \cdot \mathrm{I} 8, \mathrm{Al}_{2} \mathrm{O}_{3} \mathrm{I3} \cdot 55, \mathrm{TiO}_{2} 0.0 \mathrm{I}, \mathrm{Fe}_{2} \mathrm{O}_{3} 0.8 \mathrm{I}$, $\mathrm{CaO} 3 \cdot 38, \mathrm{MgO} 0 \cdot 06, \mathrm{~K}_{2} \mathrm{O}_{\mathrm{I}} \cdot{ }_{19}, \mathrm{Na}_{2} \mathrm{O}_{\mathrm{I} \cdot 27}, \mathrm{H}_{2} \mathrm{O}{ }_{15} \cdot 17$, sum $99 \cdot 62 \%$. The structural formula calculated on the basis of 72 oxygen atoms is: $\mathrm{Ca}_{1 \cdot 6}\left(\mathrm{Na}_{1 \cdot 1}, \mathrm{~K}_{0 \cdot 7}\right) \mathrm{Al}_{7 \cdot 2} \mathrm{Si}_{29 \cdot 1} \mathrm{Fe}_{0 \cdot 3}$ $\mathrm{O}_{72} \cdot 23 \mathrm{H}_{2} \mathrm{O}$. This can be compared with the formulae given for clinoptilolite and heulandite by Coombs et al. (1959, p. IOr): clinoptilolite $\mathrm{Ca}(\mathrm{Na}, \mathrm{K})_{4} \mathrm{Al}_{6} \mathrm{Si}_{30} \mathrm{O}_{72} \cdot 24 \mathrm{H}_{2} \mathrm{O}$; heulandite $\left(\mathrm{Ca}, \mathrm{Na}_{2}\right)_{4.8} \mathrm{Al}_{9.6} \mathrm{Si}_{26.4} \mathrm{O}_{72} .24 \mathrm{H}_{2} \mathrm{O}$ to $\left(\mathrm{Ca}, \mathrm{Na}_{2}\right)_{4} \mathrm{Al}_{8} \mathrm{Si}_{28} \mathrm{O}_{72} .24 \mathrm{H}_{2} \mathrm{O}$. A further sample of zeolite separated after dispersion in a $0.2 \% \mathrm{w} / \mathrm{v}$ solution of sodium hexametaphosphate (Calgon) contained approximately three times as much sodium and less than half as much calcium as the sample separated after dispersion in distilled water. The mineral therefore readily exchanges its calcium for sodium.

We conclude that the X-ray diffraction characteristics, chemical composition, and thermal and optical properties of the mineral clearly show that it is a zeolite of the clinoptilolite-heulandite type, but that many of its properties are intermediate between those of clinoptilolite and heulandite.

\section{Distribution}

We have looked for this zeolite in most of the important Mesozoic and Cenozoic sediments of south-east England. Fig. 2 shows the localities and horizons in which 

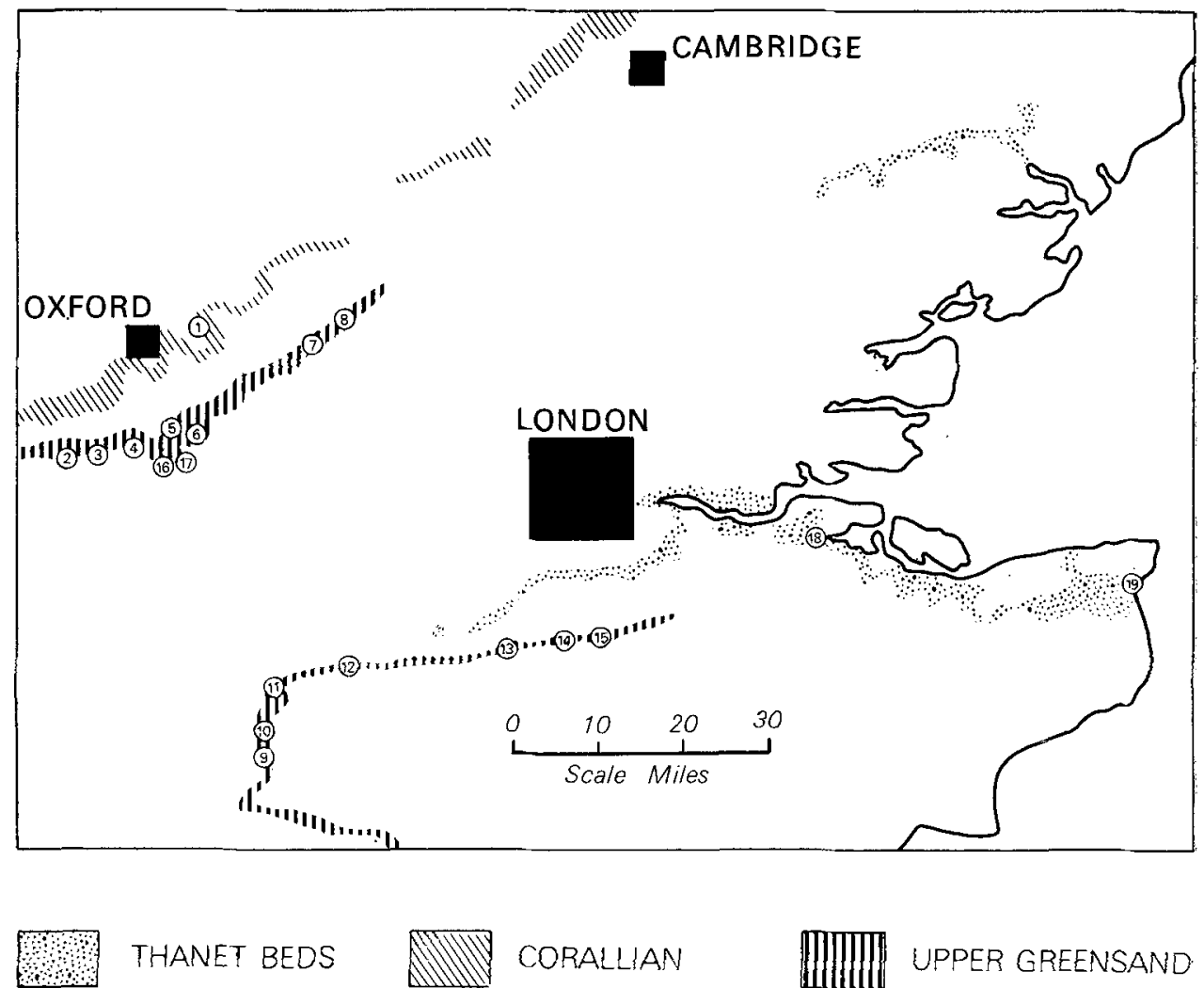

THANET BEDS

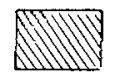

CORALLIAN

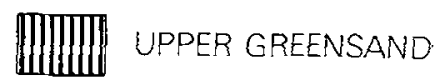

Fig. 2. Location of clinoptilolite-bearing sediments in south-east England. I. Arngrove Stone (Corallian), Shabbington Wood, Buckinghamshire (SP 616107); 2. Soil of Harwell series, Sparsholt, Berkshire (SU 34r874); 3. Malmstone, Wantage, Berkshire (SU 403880); 4. Soil of Harwell series, Harwell, Berkshire (SU 473909); 5. Malmstone, Sinodun Hills, Berkshire (SU 569920); 6. Malmstone, Shillingford Bridge, Berkshire (SU 596920); 7. Soil of Harwell series, Ellesborough, Buckinghamshire (SP 832074); 8. Soil of Harwell series, Halton, Buckinghamshire (SP 867 I 12 ); 9. Malmstone, Selborne, Hampshire (SU 745334); 10. Malmstone, West Worldham, Hampshire (SU 752360); I I. Malmstone, Lower Froyle, Hampshire (SU 769435); I 2. Malmstone, Hog's Back, Surrey (SU 9I1481); 13. Hearthstone (Upper Greensand), Brockham, Surrey (TQ 201 509); 14. Hearthstone (Upper Greensand), Merstham, Surrey (TQ 309536); I5. Firestone (Upper Greensand), Marden Castle, Godstone, Surrey (TQ 360534); I6. Chalk Marl, Cholsey, Berkshire (SU 585863); 7 . Chalk Marl, Cholsey, Berkshire (SU 591854); I8. Thanet Beds, Upnor, Kent (TQ 753700); 19. Thanet Beds, Pegwell Bay, Kent (TR 35I642).

we identified it either optically or by recognition of the main lines in its X-ray diffraction pattern. The malmstone is the most widespread source, but it also occurs locally in other facies of the Upper Greensand, in the Chalk Marl at Cholsey, Berkshire, and in the Arngrove Stone (Corallian) at Shabbington Wood near Oakley, Buckinghamshire. We found clinoptilolite in the Bullhead Bed and lowest 2-3 ft of the Thanet. Sands at Pegwell Bay (Kent) as well as at Upnor, but it does not occur at other localities in south-east England where the basal Thanet Beds are exposed. Clinoptilolite 
constitutes $10-13 \%$ of the total sediment in the basal Thanet Beds and as much as $5 \%$ of the malmstone, but is only a minor component of the other deposits.

\section{Origin}

The clinoptilolite in the malmstone is mainly authigenic, because it occurs commonly as euhedral crystals that have grown inside cavities, such as the chambers of foraminifera and carapaces of ostracods. The origin of the spherical aggregates containing opal and zeolite in the malmstone and Harwell soils is obscure. Biogenic opal is a major constituent of the rock (Hinde, I885), but none of the aggregates resemble any animal or plant opal. We therefore suggest that they formed inorganically, initially as precipitates of silica gel on the sea floor or within the sediment, and that the zeolite and crystalline silica in them formed later by diagenetic processes. In the Thanet Beds the euhedral crystals and restricted vertical distribution of the clinoptilolite also suggest an authigenic origin.

All the English clinoptilolite-bearing sediments we have studied contain almost the same assemblage of associated minerals. In the malmstone clinoptilolite is associated with amorphous silica and with low-temperature disordered cristobalite-tridymite; montmorillonite is the dominant clay mineral, and the coarse silt and fine sand fractions contain much glauconite. The main clay mineral in the basal Thanet Beds is also montmorillonite, and the coarser fractions are composed mainly of glauconite; opal and cristobalite-tridymite do not occur, but there is abundant detrital flint. The Arngrove Stone also contains montmorillonite, glauconite, and abundant opal or microcrystalline silica in the spicules of Rhaxella perforata (Davies, I907). Noncalcareous fractions of the Chalk Marl at Cholsey are also composed mainly of montmorillonite, glauconite, and flint.

Clinoptilolite is frequently formed by alteration of pyroclastic deposits (Hay, I966), and the assemblage of minerals associated with the zeolite in these English sediments resembles that formed by alteration of some volcanic materials. However, there is no direct evidence of volcanic material in any of our zeolite-containing sediments; they contain neither volcanic glass nor any minerals that are specifically volcanic in origin, and they lack the texture and microfabric of tuffaceous sediments. Further, we know of no direct evidence for contemporaneous vulcanicity during deposition of the Corallian, Upper Greensand, or Lower Chalk; Hallam and Sellwood (I968) suggested a volcanic origin for Mesozoic montmorillonitic deposits in southern England, but they provided no direct evidence for volcanoes.

The formation of montmorillonite, low-temperature disordered cristobalitetridymite, and silica-rich zeolites of the clinoptilolite-heulandite type from waterdeposited rhyolitic or dacitic ash mainly depends on the ability of the ash to provide at low temperature and pressure abundant silica in solution together with alkalis and alkaline earths (Keller, 1957; Coombs et al., 1959). The same constituents could be provided in all the zeolite-bearing sediments described in this paper by dissolution of silica from flint or biogenic opal, the removal of alkalis from glauconite, micas, or feldspars, and the dissolution of calcium carbonate. We consider that the zeolite formed diagenetically in the sediments in conditions that were chemically and physically 
equivalent to those provided by water-deposited ash, and consequently we see no need to postulate the existence of volcanos, for which there is no independent evidence.

Acknowledgements. We thank Mr. B. W. Avery, Mr. D. W. King, and Mr. M. G. Jarvis (Soil Survey of England and Wales) for supplying soil samples.

\section{REFERENCES}

Coombs (D. S.), Ellis (A. J.), FYfe (W. S.), and TAYlor (A. M.), 1959. Geochimica Acta, 17, 53-107. Davies (A. M.), x907. Quart. Journ. Geol. Soc. 63, 29-50.

FlöRKE (O. W.), 1955a. Ber. deut. keram. Ges. 32, pt. 12, 369-81.

- 1955b. Neues Jahrb. Min., Monatsh. 217-23.

Hallam (A.) and Sellwood (B. W.), 1968. Nature, 220, i I93-5.

Hay (R. L.), 1966. Geol. Soc. Amer. Spec. Pap. 85.

Hey (M. H.) and Bannister (F. A.), I934. Min. Mag. 23, 556-9.

HiNDE (G. J.), I 885. Phil. Trans. 176, pt. 2, 403-53.

K.eller (W. D.), 1957. The Principles of Chemical Weathering. Columbia, Missouri (Lucas Brothers).

Mason (B.) and Sand (L. B.), 1960. Amer. Min. 45, 341-50.

MIerkle (A. B.) and Slaughter (M.), I968. Ibid. 53, i $120-38$.

MIUMpton (F. A.), I960. Ibid. 45, 35I-69.

ShePARd (A. O.), 1961. U.S. Geol. Surv. Prof. Pap. 424-C, C320-C 323.

- and STARKEY (H. C.), 1964. Ibid. 475-D, D89-D92.

- 1966. Min. Soc. India, Int. Min. Assoc. Volume, $155-8$.

[Manuscript received I2 May 1969 ] 